\title{
DINAMIKA PENGEMBANGAN KURIKULUM PENDIDIKAN AGAMA ISLAM DI MADRASAH
}

(Studi Multi-Situs di Kabupaten Jombang)

\author{
Khoirul Umam \\ (Universitas Hasyim Asy'ari Tebuireng Jombang)
}

\begin{abstract}
Abstrak:
Dalam konteks dinamika pengembangan kurikulum di Indonesia, kurikulum PAI masih menghadapi berbagai masalah dalam pengembangannya. Hal ini disebabkan perbedaan status kepemilikan sekolah, lingkungan sekolah, dan sumber daya manusia yang tersedia. Penelitian ini bertujuan untuk menganalisa permasalahan penerapan pengembangan, konstruksi, serta faktorfaktor pendukung dan penghambat kurikulum PAI di MTs Salafiyah Syafi'iyah Tebuireng, MTs Ar-Rahman Nglaban, MTsN Plandi Diwek, dan MTsN Tambakberas Jombang. Penelitian ini menggunakan penelitian lapangan dengan studi multi-situs pada empat lembaga yang berbeda di Kabupaten Jombang. Hasil penelitian menunjukkan bahwa konstruksi kurikulum dari keempat madrasah tersebut menitikberatkan pada Subject Centered Design, yang berfokus pada mata pelajaran. Sedangkan faktorfaktor penentu yang paling dominan adalah sumber daya manusia dan sarana prasarana. Perbandingan model konstruksi kurikulum di empat madrasah tersebut terletak pada esensi dan kedalaman materi. Dari data keempat madrasah tersebut, maka collaborrative curriculum menjadi pilihan desain ulang kurikulum yang dinilai ideal dan dapat diterapkan.
\end{abstract}

Kata Kunci: Konstruksi Kurikulum; Pendidikan Agama Islam; Madrasah. 


\begin{abstract}
:
In the dynamic context of curriculum development in Indonesia, Islamic education subject encounters various problems in its curriculum development. This is caused by difference in school ownership status, school environment, and the availability of human resources. This research proposes to analyze problems in the implementation of curriculum development, curriculum construction, and factors supporting and preventing curriculum development in MTs Salafiyah Syafi'iyah Tebuireng, MTs Ar-Rahman Nglaban, MTsN Plandi Diwek, and MTsN Tambakberas Jombang. This research makes use field research approach with multi-sites within four madrasah in Jombang Regency. Results show that the four madrasah put too much attention to subject centered design. Human resources and infrastructure become dominant determining factors. Material essence and quality become distinguishing factors after the comparation. From data collected in the four madrasah, collaborative curriculum may be an ideal and applicable alternative in redesigning curriculum.
\end{abstract}

\title{
Keywords: Curriculum Construction; Islamic Education Subject; Madrasah.
}

\section{A. Pendahuluan}

Pendidikan Agama Islam (PAI) yang selama ini berlangsung agaknya terasa kurang terkait atau kurang concern terhadap persoalan tentang bagaimana mengubah pengetahuan agama yang bersifat kognitif menjadi makna dan nilai yang perlu diinternalisasikan dalam diri peserta didik untuk bergerak, berbuat,dan berperilaku secara kongkret agamis dalam kehidupan praksis sehari-hari. ${ }^{1}$

Pemahaman tentang PAI di sekolah dapat dilihat dari dua sudut pandang, yaitu PAI sebagai aktivitas dan PAI sebagai fenomena. PAI sebagai aktivitas berarti upaya yang secara sadar dirancang untuk membantu seseorang atau sekelompok orang dalam mengembangkan pandangan hidup (bagaimana orang menjalani dan memanfaatkan hidup dan kehidupannya), sikap hidup, dan keterampilan hidup baik yang bersifat manual (petunjuk praktis) maupun mental dan sikap sosial yang bernafaskan ajaran serta nilai-nilai Islam. Sedangkan sebagai fenomena adalah peristiwa perjumpaan antara dua orang atau lebih dan/atau penciptaan suasana yang dampaknya adalah berkembangnya suatu pandangan hidup yang bernafaskan ajaran atau nilai Islami yang diwujudkan dalam sikap hidup serta keterampilan hidup pada salah satu atau beberapa pihak. ${ }^{2}$

1 Muhaimin, Paradigma Pendidikan Islam, Upaya Mengefektifkan Pendidikan Agama Islam di Sekolah (Bandung: Remaja Rosdakarya, 2004), 168.

2 Muhaimin, Rekonstruksi Pendidikan Islam, dari Paradigma Pengembangan, Manajemen Kelembagaan, Kurikulum hingga Strategi Pembelajaran (Jakarta: Rajawali Press, 2009), 51; 
Keputusan Menteri Agama Republik Indonesia Nomor 165 tahun 2014 tentang Pedoman Kurikulum Madrasah 2013 mata pelajaran PAI dan Bahasa Arab disebutkan bahwa pedoman kurikulum Madrasah 2013 mata Pelajaran PAI dan bahasa Arab sebagaimana dimaksud dalam diktum kesatu berlaku secara nasional pada Madrasah Ibtidaiyah, Madrasah Tsanawiyah, dan Madrasah Aliyah. Selanjutnya pada Keputusan Menteri Agama nomor 207 tahun 2014 tentang kurikulum madrasah disebutkan pada diktum ketiga, bahwa kurikulum 2013 sebagaimana dimaksud dalam diktum kesatu meliputi Mata Pelajaran PAI dan Bahasa Arab dan pada diktum keempat disebutkan bahwa KTSP 2006 dan Kurikulum 2013 sebagaimana dimaksud dalam diktum kedua dan ketiga berlaku secara nasional pada Madrasah Ibtidaiyah, Madrasah Tsanawiyah, Madrasah Aliyah/Madrasah Aliyah Kejuruan dimulai pada semester kedua tahun pelajaran $2014 / 2015$.

Dalam realitas sejarahnya, pengembangan kurikulum PAI tersebut ternyata mengalami perubahan paradigma, walaupun dalam beberapa hal tertentu paradigma sebelumnya masih tetap dipertahankan hingga sekarang. Hal ini dicermati dan fenomena berikut: (1) perubahan dari tekanan pada hafalan dan daya ingatan tentang teks-teks dari ajaran agama Islam serta disiplin mental spiritusl sebagaimana pengaruh dari timur tengah kepada pemahaman tujuan. Makna dan motivasi beragama Islam untuk mencapai tujuan pembelajaran PAI, (2) perubahan dari cara berpikir tekstual, normatif, dan absolut kepada cara berpikir historis empiris dan kontekstual dalam memahami dan menjelaskan ajaran-ajaran dan nilai-nilai agama Islam, (3) perubahan dari tekanan pada produk atau hasil pemikiran keagamaan Islam daripada pendahulunya kepada proses metodologisnya sehingga menghasilkan produk tersebut, (4) perubahan dari pola pengembangan kurikulum PAI yang hanya mengandalkan pada para pakar dalam memilih dan menyusun isi kurikulum PAI ke arah keterlibatan yang luas dari para pakar, guru, peserta didik, masyarakat untuk mengidentifikasi tujuan PAI dan cara-cara mencapainya.

Madrasah merupakan lembaga pendidikan yang memiliki tugas yang tidak ringan dalam rangka mewujudkan cita-cita dan tujuan pendidikan baik tujuan pendidikan Islam maupun tujuan pendidikan nasional, idealisme madrasah yang kental dengan nlai-nilai karakter sudah ada sejak awal berdirinya. ${ }^{3}$ Problem yang dihadapi banyak sekali, termasuk kurikulum di

Ahmad Tafsir, Ilmu Pendidikan Islam Perspektif Islam (Bandung: PT. Remaja Rosda Karya, 2006), 32; Abdul Mudjib dan Jusuf Mudzakir, Ilmu Pendidikan Islam (Jakarta: Prananda Media, 2006), 27.

3 Tim penyusun dari Departemen Agama Republik Indonesia menetapkan bahwa madrasah pertama kali di Nusantara ini adalah Madrasah Adabiyah di Padang (Sumatera barat) yang didirikan oleh Syekh Abdullah Ahmad pada tahun 1909.Nama resminya Adabiyah School pada tahun 1915 diubah menjadi HIS Adabiyah. Pada tahun 1910 di Padang juga didirikan sekolah agama dengan nama Madrasah School yang pada tahun 1923 menjadi Diniyah School. Madrasah ini didirikan dengan harapan dapat mencetak ahli agama yang mampu berkomunikasi dengan 
dalamnya, dengan munculnya perubahan-perubahan yang ada pada kurikulum mulai dari KBK, KTSP sampai kurikulum 2013 madrasah mencoba untuk melakukan adaptasi dan mengikutinya dengan berbagai bentuk kegiatan, dengan pengembangan kurikulum tersebut madrasah tidak hanya adaptif dan bahkan tergilas oleh perubahan kurikulum tersebut, namun hendaknya mampu menunjukkan idealisme nilai-nilai Islam sebagai ruh yang dimilikinya.

Problem akademis yang menjadi inspirasi penelitian ini adalah: (1) problemaspek kelembagaan, (2) problem aspek kurikulum, dan (3) problem aspek tenaga pengajar. Pada aspek kelembagaan bahwa penerapan pendidikan Islam jika mengandalkan pada lembaga lembaga pendidikan negeri sangatlah tidak mungkin karena pembelajaran agama di sekolah negeri sangat minim. Satu satunya harapanyang masih dapat ditempuh adalah pembenahan pada lembaga pendidikan madrasah, pesantren atau sekolah sekolah Islam semacam lembaga pendidikan Islam terpadu. Kenyataan di lapangan lembaga pendidikan Islam khususnya madrasah sebagai institusi pendidikan yang menampung aspirasi sosial budaya agama penduduk muslim Indonesia yang sudah lama hidup dan secara kultural berakar kuat dalam peta pendidikan di Indonesia, sampai saat ini masih menampakkan sistem yang dikotomis. Pola pembinaan kelembagaan pendidikan yang dilakukan oleh pemerintah melalui Kemendiknas dan Kemenag mengesankan kebijakan pendidikan yang dualistis dan pola ini menyimpan banyak persoalan.

Paparan di atas memperlihatkan adanya masalah-masalah kurikulum PAI pada dinamika kurikulum di Indonesia, masalah-masalah pengembangan kurikulum PAI, masalah-masalah kurikulum PAI pada variasi status dan lingkungan sekolah, serta masalah-masalah yang berkaitan dengan sumber daya manusia (SDM). Sejumlah masalah ini selanjutnya memerlukan identifikasi sehingga dapat diperoleh deskripsi secara lebih spesifik. Dari identifikasi masalah ini diperlukan pemilihan masalah dan penentuan objek penelitian secara jelas agar dapat dipastikan fokus penelitiannya.

Penelitian ini melihat bahwa indikasi adanya masalah-masalah tersebut dapat ditemui pada empat madrasah di wilayah Kabupaten Jombang, yaitu MTs Salafiyah Tebuireng, MTs Ar-Rahman Nglaban, MTsN Plandi Diwek dan MTsN Tambakberas Jombang. Empat madrasah ini memiliki profil dan status yang berbeda, sehingga urgen dan menarik untuk diteliti dengan tipe penelitian multikasus. Empat madrasahini berpotensi untuk diteliti pada aspek konstruksi dan pengembangan kurikulumnya.

Berdasarkan data lapangan pada keempat madrasah hasil interviu pendahuluan peneliti melihat adanya konstruksi kurikulum yang dilakukan pada masing-masing madrasah, konstruksi tersebut memiliki konsekuensi logis terhadap perkembangan dan peningkatan sumber daya manusia guru yang ada

perkembangan ilmu pengetahuan umum dan mengurangi perbedaan antara lembaga pendidikan Islam dengan lembaga pendidikan sekuler bentukan penjajah. 
di dalamnya, kendala pada tahap implementasi membutuhkan sikap keteguhan. Atas dasar data itulah penulis tertarik untuk melakukan penelitian tentang Konstruksi dan Pengembangan Kurikulum PAI di Madrasah (Studi Multikasus di MTs Salafiyah Tebuireng, MTs Ar-Rahman Nglaban, MTsN Plandi Diwek dan MTsN Tambakberas Jombang).

\section{B. Paparan Data Penelitian}

\section{MTs Salafiyah Syafi'iyah Tebuireng}

\section{a. Bentuk Konstruksi Kurikulum}

Menurut Miftahul Huda, SH (Kepala Madrasah)dan Sri Ratnasari, S.Pd. (Waka Kurikulum), bahwa madrasah berkomitmen bahwa ciri khas pesantren juga menjadi perioritas.Hal ini berawal dari analisis bersama terhadap lulusan Madrasah Tsanawiyah yang ternyata sangat minim penguasaan ilmu-ilmu agama khususnya bidang ilmu alat dan penguasaan bahasa, betapapun resiko yang harus dihadapi program ini tetap berjalan.Tentu program ini memiliki tujuan yang tinggi, diantaranya sebagai berikut: (1) membentuk peserta didik yang memiliki kerangka berfikir berlandaskan al-Qur'an, al-Sunnah, dan kitabkitab salaf, (2) membentuk peserta didik yang memiliki karakter santri yang kuat, antara lain Ikhlas, Jujur, kerja keras, tanggung Jawab, dan toleransi, (3) membentuk peserta didik yang mampu menerapkan kemampuan berbahasa arab dalam mempelajari/mengkaji kitab-kitab salaf.

Seperti penjelasan Muhaimin yang dikutip oleh Mujamil, bahwa kurikulum madrasah perlu dikembangkan secara terpadu dengan menjadikan ajaran dan nilai-nilai agama sebagai petunjuk dan sumber konsultasi bagi pengembangan berbagai mata pelajaran umum, yang operasionalnya dapat dikembangkan dengan cara mengimplementasikanajaran dan nilai-nilai Islam kedalam bidang studi IPA, IPS dan sebagainya, sehingga kesan dikotomis tidak terjadi. Kemudian model pembelajaran dapat dilakukan dengan cara team teaching, yakni guru bidang studi IPA, IPS dan lainnya bekerja sama dengan guru PAI dalam menyusun desain pembelajaran secara konkrit dan detail, untuk diimplementasikan dalam pembelajaran. ${ }^{4}$

Selanjutnya Muhammad Subhan ${ }^{5}$ (Waka kurikulum)menuturkan bahwa konstruksi kurikulum di MTs Salafiyah Syafi'iyah Tebuireng berbasis mata pelajaran.Hal ini dibuktikan dengan adanya proses yang dilakukan dalam konstruksi kurikulum tersebut diawali dengan kegiatan identifikasi terhadap kedalaman materi pelajaran yang ada. Untuk memperkuat proses tersebut dibentuklah tim pengembang kurikulum madrasah.Tim ini berkonsentrasi terhadap perencanaan, pelaksanaan dan penilaian yang seharusnya dilakukan.

\footnotetext{
${ }^{4}$ Mujamil Qomar, Manajemen Pendidikan Islam (Jakarta: Erlangga, 2008), 157-158.

5 Muhammad Subhan, Wawancara, MTs Salafiyah Syafi'iyah Tebuireng, 4 Februari 2017.
} 
Dengan perspektif Subject Centered Desaign (SCD) sebagaimana dijelaskanoleh Ornstein dan Hunkins dalam bukunya Curriculum: Foundation, Prinsciples, and Theory maka dapat dipahami bahwa subject centered design (SCD) pada madrasah ini menerapkan bentuk-bentuk nya sebagai berikut: pertama, bentuk Subject Matter Design (SMD). Pada bentuk subject matter design ini bahan atau isi kurikulum disusun dalam bentuk mata pelajaran yang terpisah-pisah, misalnya mata pelajaran, al-qur'an hadits, fikih, akidah akhlaq, dan sejarah kebudayaan Islam. Mata pelajaran itu tidak berhubungan satu sama lain. Pada kegiatan proses belajar mengajar, setiap guru hanya bertanggungjawab pad mata pelajaran yang diajarkannya. Pada desain ini berkeyakinan bahwa yang menajdikan manusia berbeda dengan makhluk lainnya adalah dari kecerdasan mereka, dengan kata lain bahwa dalam merencanakan atau mengkonstruk kurikulum akan lebih baik jika dipusatkan pada mata pelajaran.

Kedua, bentuk diciplines design (DD), bentuk ini merupakan bentuk pengembangan dari subject matter design, keduanya masih menekankan isi atau materi kurikulum. Perbedaannya adalah pada subject matter design belum ada kriteria yang tegas tentang apa yang disebut subject atau ilmu. Sementara pada diciplines design kriteria tersebut telah tegas, yang membedakan adalah apakah suatu pengetahuan itu.Perbedaan yang lain terletak pada tingkat penguasaan. Bentuk ini memiliki beberapa kelebihan diantaranya:(1) kurikulum model ini memiliki organisasi yang sistemik, efektif dan dapat memelihara integrasi intelektual manusia, (2) peserta didik tidak hanya menguasai serentetan fakta tetapi dapat menguasai konsep, hubungan, dan proses-proses intelektual yang berkembang pada siswa.

Ketiga, bentuk Broad Filed Design (BFD), bentuk ini merupakan pengembangan dari subject design dan disciplines design. Bentuk ini berusaha untuk menghilangkan pemisahan dengan mengembangkan the broad field deisgn yakni desain yang menyatukan beberapa mata pelajaran yang berdekatan atau berhubungan menjadi satu bidang studi. Broad field sudah merupakan perpaduan atau fusi dari sejumlah mata pelajaran yang berhubungan. Ciri umum dari broad field ini adalah kurikulum terdiri dari suatu bidang pengajaran di mana di dalamnya berpadu sejumlah mata pelajaran yang saling berhubungan. Sedangkan tujuan dari desain ini adalah menyiapkan para siswa yang dewasa hidup dalam dunia informasi yang sifatnya spesial dengan pemahaman yang bersifat menyeluruh.

Meskipun subject centered design sebagai pilihan dalam mengkonstruksi kurikulum di madrasah ini, menurut penulis, madrasah masih lebih dominan pada penggunaan bentuk subject matter design hal ini masih tercermin pada terpisahnya masing-masing mata pelajaran yang dituangkan dalam kurikulum, sedangkan dua bentuk yang lain masih belum nampak, meskipun 
sesungguhnya bentuk broad field design dapat dijadikan alternatif sebagai bentuk yang mampu menyiapkan kompetensi siswa pada spesialisasi badangbidang tertentu. Artinya bahwa dalam mengkonstruk kurikulum madrasah tidak hanya berkonsentrasi pada satu bentuk saja tetapi juga perlu memasukkan bagian-bagian penting dari bentuk yang lain, dengan asumsi bahwa kurikulum pendidikan selalu mengalami perkembangan, termasuk kurikulum pendidikan di madrasah.

\section{b. Pengembangan Kurikulum PAI}

Berkaitan dengan pengembangan kurikulum PAI yang dilakukan di MTs Salafiyah Syafi'iyah Tebuireng sebagaimana yang dituturkan oleh Miftahul Huda dan Sri Ratnasari, bahwa dalam pengembangan kurikulum PAIMTsSalafiyah Syafi'iyah Tebuireng telah memenuhi prinsip-prinsip pengembangan kurikulum sebagaimana yang telah diutarakan oleh Abdullah Idi, bahwa pada prinsip relevansi tersebut bahwa pendidikan itu dikatakan relevan apabila hasil yang diperoleh akan berguna bagi kehidupan seseorang. ${ }^{6}$

Dalam perspektif Sukmadinata, terkait dengan prinsip relevansi terdapat dua relevansi yang harus dimiliki dalam program kurikulum yakni relevansi keluar dan relevansi kedalam. Relevansi keluar diantaranya; (1) kesesuaian antara pendidikan dan lingkungan siswa, (2) kesesuaian antara pendidikan dengan kehidupan anak didik saat sekarang dan yang akan datang, (3) kesesuaian antara pendidikan dengan dunia kerjanya bagi siswa, dan (4) kesesuaian antara pendidikan dengan perkembangan ilmu pengetahuan dan teknologi. Selain hal tersebut menurutnya bahwa kurikulum juga harus memiliki relevansi di dalam yaitu adanya kesesuaian antara tujuan, isi dan proses penyampaian dan penilaian. Relevansi internal ini menunjukkan suatu keterpaduan kurikulum7.

Selanjutnya, Sri Ratnasari menjelaskan bahwa dalam pengembangan kurikulum madrasah terdapat esensi pendekatan humanistik. Pendekatan ini lebih memberikan tempat kepada siswa seluas-luasnya. Dalam kurikulum pendekatan humanistik ini juga guru diharapkan dapat membangun hubungan emosional yang baik dengan peserta didiknya, oleh karenya peran guru yang diharapkan sebagai berikut: (1) mendengar pandangan realitas peserta didik secara komprehensif, (2) menghormati individu peserta didik, dan (3) tampil secara alamiah, otentik dan tidak dibuat-buat. Dalam pendekatan ini pula peserta didik diajar untuk membedakan hasil berdasarkan maknanya. Kurikulum ini melihat kegiatan sebagai sebuah manfaat untuk peserta dimasa depan. Sesuai dengan prinsip yang dianut, kurikulum ini menekankan

${ }^{6}$ Abdullah Idi, Pengembangan Kurikulum Teori dan Praktik (Yogyakarta: Ar-Ruzz Media, 2010), 179.

7 Nana Syaodih Sukmadinata, Pengembangan Kurikulum: Teori dan Praktik (Bandung: PT. Remaja Rosdakarya, 1997), 124. 
integritas, yaitu kesatuan perilaku bukan saja yang bersifat intelektual tetapi juga emosional dan tindakan.

Selanjutnya Muhammad Subhan8juga menuturkan bahwa dalam pengembangan kurikulum di madrasah ini tampak mendekati kesempurnaan, jika dilihat dari berbagai komponen-komponen yang ada dalam pengembangan kurikulum pada umumnya. Komponen-komponen tersebut diantaranya: (1) komopnen tujuan kurikulum, (2) komponen organisasi kurikulum, (3) komponen isi atau materi pelajaran,(4) komopnen media atau sarana dan prasarana, dan (5) komponen metode atau strategi pembelajaran. Menurut peneliti, bahwa lima komponen ini seperti yang telah dipaparkan oleh Subandiyah ${ }^{9}$ yaitu; (1) komopnen tujuan kurikulum, (2) komponen organisasi kurikulum, (3) komponen isi atau materi pelajaran, (4) komopnen media atau sarana dan prasarana, dan (5) komponen metode atau strategi pembelajaran.

Berkaitan dengan komponen evaluasi dalam pengembangan kurikulum, dalam perspektif Murry Print ${ }^{10}$ bahwa: suatu evaluasi tentang kinerja peserta didik dalam suatu konteks tertentu, evaluasi seperti ini pada dasarnya berusaha menentukan seberapa bagus peserta didik telah mencapai tujuan-tujuan instruksional khusus yang telah ditetapkan terutama tentang situasi belajar. Buku hasil belajar (raport) sebagai contoh dari evaluasi produk. Sedang evaluasi yang berkaitan dengan kegiatan proses adalah menguji pengalamanpengalaman dan kegiatan-kegiatan yang tercakup dalam situasi belajar.

Apa yang diutarakan oleh Murry Print mempertegas bahwa komponen evaluasi dalam pengembangan kurikulum menurut penulis mesti harus ada karena dengan adanya komponen evaluasi tersebut akan dapat diketahui sejauh mana perkembangan dan keberhasilan kurikulum yang telah disusun sebelumnya. Hal senada juga dituturkan oleh Muhammad Ali11 bahwa evaluasi terhadap kurikulum bukan semata-mata dilakukan terhadap salah satu komponen atau elemen saja, melainkan seluruh komponen atau elemen baik tujuan, bahan/muatan, organisasi kurikulum, metode maupun proses evaluasi itu sendiri.

Menurut peneliti, bahwa apa yang telah dilakukan madrasah dalam melakukan pengembangan kurikulum PAI belum sepenuhnya melalui tahaptahap yang sebagaimana diutarakan oleh Oemar Hamalik tersebut. Madrasah masih cenderung menggunakan tiga tahapan yang sering dilakukan dalam proses kegiatan, yaitu tahap perencanaan, pelaksanaan dan penilaian atau evaluasi. Apabila dicermati lebih mendetail ada beberapa tahapan-tahapan yang

\footnotetext{
8 Muhammad Subhan, Wawancara, MTs Salafiyah Syafi'iyah Tebuireng, 4 Februari 2017.

${ }^{9}$ Subandiyah, Pengembangan dan Inovasi Kurikulum (Jakarta: Raja Grafindo Persada, 1993), 9.

${ }_{10}$ Murray Print, Curriculum Development and Design (Sydney: Allen and Unwin, 1993), dalam Abdullah Idi, Pengembangan Kurikulum, 142.

${ }^{11}$ Muhammad Ali, Pengembangan Kurikulum di Sekolah (Bandung: Sinar Baru, 1992), 124.
} 
belum terwakili, misalnya tahap pengembangan rencana untuk melaksanakan kurikulum, tahap pelaksanaan uji coba kurikulum di lapangan dan tahap pelaksanaan perbaikan dan penyesuaian.

\section{c. Faktor-Faktor Pendukung dan Penghambat}

Dokumen kurikulum madrasah sebagai pendukung tersebut, SDM atau sumber daya manusia guru menjadi faktor yang juga dominan dalam mengkonstruksi kurikulum. Hal ini dimaksudkan bahwa keterlibatan guru sebagai pelaku kurikulum di madrasah tidak dapat dianggap kecil. Selain itu terdapat faktor yang menghambatnya, dan harus dilakukan analisis pada faktor-faktor tersebut, jika itu sebagai penghalang maka bagaimana faktor-faktor itu dapat menjadi penguat, jika itu sebagai kelemahan maka bagaimana faktor-faktor itu menjadi kekuatan, sehingga konstruksi kurikulum menjadi efktif dan efesien.

Dalam mengkonstruk kurikulum tersebut yang paling dominan hambatan ada pada guru atau tenaga pendidik, biasanya guru kurang berpartisipasi dalam pengembangan kurikulum tersebut disebabkan oleh, pertama, kurangnya waktu yang dimiliki oleh guru. Ini dimaksud di samping guru berprofesi sebagai tenaga pengajar juga mempunyai pekerjaan sampingan di luar profesinya, dengan alasan untuk memenuhi beban kebutuhan hibup, sehingga dengan profesi sampigan tersebut guru tidak punya banyak waktu untuk berfikir dan fokus terhadap materi yang diajarkannya.

Kedua, adanya perbedaan pengalaman dan disiplin ilmu yang ditekuni oleh guru. Perbedaan ini menyebabkan terjadinya beda pendapat yang mengakibatkan sulitnya lembaga pendidikan untuk melakukan pengembangan kurikulum. Ketiga, kemampuan dan pengetahuan ilmu guru itu sendiri. Sumber daya manusia di lembaga pendidikan sangat menentukan dan menjadi faktor utama dalam memajukan lembaganya. Salah satu faktor yang menjadi penghambat dalam pengembangan kurikulum adalah keterbatasan sumber daya manusia.

\section{MTs Ar-Rahman Nglaban}

\section{a. Bentuk Konstruksi Kurikulum}

Dalam mengkonstruk kurikulum madrasah berdasarkan mata pelajaran. Kurikulum disusun berpusat pada isi atau materi yang akan diajarkan, kurikulum tersusun atas sejumlah mata pelajaran, dan mata pelajaran tersebut diajarkan secara terpisah, karena demikian maka kurikulum ini biasa disebut juga separated subject curriculum.

Harisun Indah menjelaskan bahwa bentuk desain kurikulum yang ada di madrash ini bersifat atau model kurikulum terpisah atau sering disebut Subject Centered Design. Kurikulum ini merupakan bentuk desain yang paling populer dan paling banyak digunakan. Dalam Subject Centered Design ini kurikulum 
dipusatkan pada isi atau materi yang akan diajarkan. Kurikulum disusun atas sejumlah mata pelajaran, dan mata-mata pelajaran tersebut diajarkan secara terpisah. Karena terpisah-pisahnya itu maka kurikulum ini disebut juga separated subject curriculum. Subject centered design berkembang dari konsep pendidikan klasik yang menekankan pengetahuan, nilai-nilai dan warisan budaya masa lalu, dan berupaya untuk mewariskannya kepada generasi berikutnya. Karena mengutamakan isi atau bahan ajar atau subject matter tersebut, maka desain kurikulum ini disebut juga subject academic curriculum.

Model design curriculum mempunyai beberapa kelebihan dan kekurangan. Beberapa kelebihan dari model desain kurikulum ini adalah: (1) mudah disusun, (2) mudah dilaksanakan, (3) mudah dievaluasi, (4) mudah disempurnakan, (5) tidak perlu disiapkan tenaga pengajar khusus artinya jika telah menguasai ilmu dan bahan yang diajarkannya dipandang sudah dapat menyampaikannya. Sedang kekurangan dari model ini adalah: (1) bertentangan dengan kenyataan karena materi disampaikan secara terpisah, (2) peran peserta didik pasif karena mengutamakan bahan ajar, (3) pengajaran lebih bersifat verbalitas dan kurang praktis karena pengajaran lebih menekankan pengetahuan dan kehidupan masa lalu. Atas dasar tersebut maka hendaknya madrasah dapat melakukan perbaikan ke arah yang lebih terintegrasi, praktis dan bermakna serta memberikan peran yang lebih aktif kepada siswa.

Berdasarkan uraian di atas madrasah masih belum mampu untuk mengkonstruk kurikulum yang terintegrasi, meskipun demikian upaya untuk mempertajam terhadap kompetensi masing-masing mata pelajaran telah dilakukan secara maksimal, ini terbukti dengan adannya rencana penentuan dan pemilihan beberapa kompetensi yang harus dicapai siswa di masingmasing mata pelajaran lebih terinci muatan dan waktunya. Artinya terdapat batasan-batasan yang jelas dari masing-masing mata pelajaran dengan tetap mempertimbangkan kaidah dan standar kompetensi yang ditetapkan oleh madrasah.

\section{b. Pengembangan Kurikulum PAI}

Berkaitan dengan pengembangan kurikulum PAI di MTs Ar-Rahman Nglaban ini dapat diketahui bahwa yang dilakukan oleh madrasah difokuskan kepada dua hal, yakni, (1) langkah-langkah atau mekanisme dalam pengembangan kurikulum, dan (2) model pengembangan kurikulum itu sendiri.Untuk mengetahui data tersebut, sebagaimana paparan Harisun Indah menggambarkan bahwa proses pengembangan kurikulum di madrasah ini telah melalui mekanisme seperti halnya pengembangan pada kegiatan-kegiatan lainnya, yakni dari perencanaan, kemudian pelaksanaannya, dan selanjutnya terdapat proses evaluasi, meskipun sebenarnya masih terdapat beberapa mekasnisme dalam pengemabangan kurikulum yang belum dilakukan. 
Menurut Hamalik, pengembangan kurikulum harus melalui beberapatahapan, yaitu: (1) studi kelayakan dan kebutuan, (2) penyusunan konsep awal perencanaan, (3) pengembangan rencana untuk untuk melaksanakankurikulum, 4) pelaksanaan uji coba kurikulum, (5) pelaksanaan kurikulum, (6) pelaksanaan penilaian dan pemantauan kurikulum, dan (7) pelaksanaan perbaikan kurikulum. ${ }^{12}$

Jika dilihat dari perspektif Hamalik, terdapat empat tahapan yang belum dilakukan oleh madrasah ini dalam pengembangan kurikulum.Meskipun demikian, menurut peneliti, bahwa tiga tahapan tersebut telah mewakilinya. Namun demikian, apabila tiga tahapan yang telah dilakukan tersebut sesuai dengan prosedur yang sesungguhnya, maka hasil dari pengembangan kurikulum tersebut menjadi optimal, jika tidak, maka akan terjadi sebaliknya.

Hal lain yang dapat ditangkap oleh peneliti bahwa pada proses perencanaan tersebut terdapat rumusan-rumusan materi, rumusan-rumusan tujuan, rumusan-rumusan metode dan strategi yang akan digunakan, ini berarti bahwa dalam pengembangan kurikulum tersebut juga mengandung unsur atau komponen-komponen penting dalam pengembangan kurikulum. Sebagaimana yang juga telah diutarakan oleh Robert S. Zais ${ }^{13}$ bahwa terdapat tiga komponen utama dari kurikulum yakni, komponen tujuan, komponen isi atau materi dan komponen metode atau strategi pembelajaran.

Sumantrimengemukakan bahwa evaluasi ini dilakukan untuk mengetahui, menelusuri, atau menjajagi keadaan dan kemajuan peserta didik, praktik, materi dan program pendidikan. Evaluasi merupakan titik awal dan titik akhir atau alat dalam pemantauan terhadap kesinambungan dan pembaharuan pendidikan. ${ }^{14}$

Peneliti melihat apa yang dilakukan oleh madrasah sudah nampak bahwa model pengembangan kurikulum tersebut telah menunjukkan pekerjaan yang serius, hanya saja yang terjadi di lapangan bahwa pada tahap implementasi dan evaluasinya masih belum berjalan secara maksimal. Namun upaya-upaya optimalisasi pada tahap-tahap tersebut terus dilakukan oleh madrasah, hal ini dibuktikan dengan adanya sebuah inventarisasi dokumen-dokumen penting yang berkaitan dengan temuan-temuan saat implementasi itu dilakukan.

Dalam perspektif John, M. Marse, ${ }^{15}$ evaluasi kurikulum berbeda dengan jenisjenis evaluasi pendidikan lainnya yang memfokuskan pada guru-guru dan

12 Oemar Hamalik, Manajemen Pengembangan Kurikulum (Bandung: Rosda, 2006) , 142.

13 Robert S. Zais, Curriculum: Principles and Foundations (New York: Harper Row Publisher, 1976), 346-350. Lihat juga Sukmadinata, Pengembangan Kurikulum Teori dan Praktik, 3.

14 Mulyani Sumantri, Pengembangan dan Pelaksanaan Kurikulum yang Menjamin Tercapainya Lulusan yang Kreatif, dalam Kurikulum untuk Abad 21 (Jakarta: Grafindo Persada, 1994), 11.

15 Janice, M. Marse, Critical Issues in Qualitative Research Methods (London: SAGE Publications, 1993) , Hendyat Soetopo dan W. Soemanto, Pembinaan dan Pengembangan Kurikulum (Jakarta: Bina Aksara, 1986), 137. 
peserta didik berinteraksi di sekitar kurikulum atau silabus khusus. Evaluasi kurikulum mencakup suatu pengujian tentang tujuan-tujuan umum rasional dan struktur tentang kurikulum atau suatu kajian tentang konteks di mana interaksi dengan para peserta didik terjadi (termasuk masukan-masukan dari para orang tua peserta didik dan masyarakat), dan suatu analisis tentang minat, motivasi dan kemampuan dari para peserta didik yang mempunyai pengalaman tentang suatu kurikulum khusus.

\section{c. Faktor-Faktor Pendukung dan Penghambat}

Selanjutnya, berkaitan dengan faktor-faktor pendukung dan penghambatdalam mengkonstruk kurikulum madrasah sebagaimana diutarakanolek Lukuk Faridah, bahwa untuk mengoptimalkan terhadap pelaksanaan konstruksi kurikulum PAI di madrasah ini perlu dilakukan berbagai strategi dalam rangka meningkatkan kualitas pada faktor-faktor pendukung yang ada untuk dikembangkan sebagai pendorong serta mengantisipasi atau meminimalisasi pada faktor-faktor penghambatnya sekaligus menjadi ukuran terhadap kualitas kurikulum yang dihasilkan.

\section{MTsN Plandi Diwek}

\section{a. Bentuk Konstruksi Kurikulum}

Berkaitan dengan konstruksi kurikulum serta implementasinya, Leny Agustin, selaku waka kurikulum menjelaskan bahwa sebelum mengkonstruksi kurikulum madrasah terlebih dahulu menggali masalah-masalah yang muncul di masyarakat khususnya masyarakat sebagai stakeholders di lingkungan sekolah, karena input siswa di madrasah ini tentu sangat beragam kemampuan yang dimiliki oleh siswa.Input siswa di madrasah ini sangat kompleks. Pada kenyataannya, banyak juga siswa yang berasal dari sekolah dasar yang penguasaan ilmu-ilmu alat keagamaaan masih sangat kurang dan juga sebaliknya. Hal ini menjadikan madrasah harus jeli untuk menganalisis tingkat kemudahan dan kesulitan materi yang akan dituangkan dalam kurikulum.

Lebih lanjut Leny Agustin memaparkan bahwa ada hal-hal prinsip yang mesti perlu diperhatikan dalam mendesain kurikulum, sebagaimana yang diutarakan oleh Hamalik ${ }^{16}$, bahwa setidaknya ada delapan prinsip mendesain kurikulum.Pertama, desain kurikulum harus memudahkan dan mendorong seleksi serta pengembangan semua jenis pengalaman belajar yang esensial bagi pencapaian prestasi belajar sesuai dengan hasil yang diharapkan. Kedua, desain kurikulum memuat berbagai pengalaman belajar yang bermakna dalam rangka merealisasikan tujuan-tujuan pendidikan, khususnya bagi kelompok siswa yang belajar dengan bimbingan guru. Ketiga, desain kurikulum harus memungkinkan

16 Oemar Hamalik, Dasar-dasar Pengembangan Kurikulum (Bandung: Remaja Rosdakarya, 2008),62. 
dan menyediakan peluang bagi guru untuk menggunakan prinsip-prinsip belajar dalam memilih, membimbing, dan mengembangkan berbagai kegiatan di sekolah. Keempat, desain kurikulum harus memungkinkan guru untuk menyesuaikan pengalaman dengan kebutuhan, kapasitas, dan tingkat kematangan siswa. Kelima, desain kurikulum harus mampu mendorong guru mempertimbangkan berbagai pengalaman belajar anak yang diperoleh di luar sekolah dan mengaitkannya dengan kegiatan belajar di sekolah. Keenam, desain kurikulum harus menyediakan pengalaman belajar yang berkesinambungan, agar kegiatan belajar siswa berkembang sejalan dengan pengalaman terdahuludan terus berlanjut pada pengalaman berikutnya. Ketujuh, kurikulum harus didesain agar dapat membantu siswa mengembangkan watak, kepribadian, pengalaman, dan nilai-nilai demokrasi yang menjiwai kultur. Kedelapan, desain kurikulum harus realistis, layak, dan dapat diterima.

Apa yang telah dilakukan oleh MTsN Plandi Diwek Jombang dalam mengkonstruk kurikulum sebenarnya tidak jauh beda dengan ketiga madrasah lainnya yakni MTs Salafiyah Syafi'iyah Tebuireng, MTs Ar-Rahman Nglaban dan MTsN Tambakberas Jombang, yakni desain kurikulum yang dipilih adalah model subject centered design. Meskipun demikian masih terdapat aspek-aspek atau komponen-komponen yang membedakan diantara keempat lembaga tersebut.Komponen dimaksud misalnya perihal struktur mata pelajaran yang ada dan dikembangkan di masing-masing madrasah, karena perbedaan tempat dan status madrasah juga menyebabkan berbedanya keinginan untuk memiliki ciri khas kompetensi masing-masing.

\section{b. Pengembangan Kurikulum PAI}

Tentang pengembangan kurikulum madrasah juga seperti yang dipaprkan oleh Leny Agustian, bahwa dalam pengembangan kurikulum di madrasah ini terdapat dua hal pokok, yaitu: (1) tentang tahapan-tahapan pengembangan kurikulum, dan (2) pendekatan-pendekatan dalam pengembangan kurikulum. Pada tahapan pengembangan kurikulum tersebut ada tiga tahapan, yakni a) tahap perencanaan, b) tahap pelaksanaan, dan (3) tahap evaluasi atau penilaian.

Menurut peneliti, apa yang telah dilakukan madrasah madrasah telah mengambil sebagaimana yang diutarakan oleh Oemar Hamalik, meskipun tidak semuanya, karean menurut Oemar Hamalik ${ }^{17}$ terdapat tujuh tahapan dalam pengemabangan kurikulum, sedangkan madrasah hanya mengambil tiga poin yang dianggap penting saja. Namun demikian tiga tahapan tersebut menurut peneliti telah mewakili pada tahapan yang lainnya.

${ }^{17}$ Hamalik, Manajemen Pengembangan, 142. 


\section{c. Faktor-Faktor Pendukung dan Penghambat}

Berkaitan dengan faktor-faktor pendukung dan penghambat dalam mengkonstruks kurikulum madrasah sebagaimana diutarakan oleh Leny Agustin, bahwa upaya untuk menyempurnakan yang dilakukan madrasah terhadap faktor pendukung tetap dilakukan semaksimal mungkin, begitu juga dalam mengantisipasi dan mencari solusi untuk faktor-faktor yang menghambtnya, pada faktor pendidik sekolah melakukan kegiatan-kegiatan yang mampu meningkatkan kompetensinya, seperti pelatihan-pelatihan, workshop, dan musyawarh guru mata peajaran (MGMP), melalui kegiatan tersebut bervariasi komptensinya guru dapat ditingkatkan.

\section{MTsN Tambakberas Jombang}

\section{a. Bentuk Konstruksi Kurikulum}

Sebelum mengkonstruk atau mendesain kurikulum madrasah terlebih dahulu menggali masalah-masalah yang muncul di masyarakat khususnya masyarakat pesantren, karena input siswa di madrasah lingkungan pesantren tentu sangat berbeda dengan input madrasah di luar pesantren, input siswa di madrasah lingkungan pesantren lebih komplek. Pada kenyataannya banyak juga siswa yang berasal lulusan sekolah dasar yang penguasaan ilmu-ilmu alat keagamaaan masih sangat kurang dan juga sebaliknya. Hal ini menjadikan madrasah harus jeli untuk menganalisis tingkat kemudahan dan kesulitan materi yang akan dituangkan dalam kurikulum.

Dalam mengkonstruk kurikulum yang akan dilaksanakan benar-benar selektif dengan berbagai analisis yang mendalam karena sesunggunhya pembelajaran pada hakikatnya proses interaksi antar peserta didik dengan lingkungannya, sehingga terjadi perubahan tingkah laku ke arah yang lebih baik. Jika konstruksi kurikulum tidak dapat atau belum mengakomodir itu semua maka kompetensi output madrasah tidak sesuai dengan yang diharapkan. Meskipun konstruksi yang dilakukan berbasis pada materi pelajaran, hendaknya muatan materi tetap pada koridor ke-khasan kepesantrenan, karena sesungguhnya model, metode dan materi yang telah diterapkan dan berjalan dalam pesantren dapat dijadikan sebagai acuan pembelajaran.

Berkaitan dengan kurikulum madrasah yang di bawah naungan pesantren tentu tidak lepas dari dua model kurikulum yang selama ini dikenal yakni, model kurikulum salafi dan model kurikulum khalafi atau modern. Ukuran kelulusan dan keberhasilan seorang siswa atau santri pada model salafi ini betul-betul ditentukan oleh kepiawaiannya dalam penguasaan kitab kuning. Penguasaan dalam hal ini adalah tidak sekedar bisa membaca dengan benar, tetapi juga memahami, mengungkapkan, mengembangkan dan mengkontekstualisasikan kandungannya. 
Berdasarkan uraian tersebut di atas, maka desain kurikulum madrasahdi bawah naungan pesantren dapat dikembangkan melalui: 1) melakukankajian kebutuhan (need assesment) untuk memperoleh faktor-faktor penentu kurikulum serta latar belakangnya, 2) menentukan mata pelajaran yang akan diajarkan sesuai dengan kebutuhan dan lingkup urutannya, 3) merumuskan tujuan yang diharapkan, 4) menentukan standar hasil belajar yang diharapkannya sehingga keluarannya dapat terukur, 5) menentukan kitab yang dijadikan pedoman materi ajar dan ditentukan urutan kelompoknya, 6) menentukan syarat yang harus dikuasai siswa untuk mengikuti pelajaran pada tingkat kelompoknya, 7) menentukan strategi pembelajaran yang serasi dan menyediakan berbagai sumber dalam proses pembelajaran, 8) menentukan alat evaluasi penilaian hasil belajar, dan 9) membuat rancangan rencana penilaian kurikulum secara keseluruhan dan strategi pembelajaran berkelanjutan.

Apa yang telah dilakukan oleh MTsN Tambakberas dalam mengkonstruksi kurikulum PAI secara garis besar telah memilih subject centered design sebagai model desain yang diterapkan di madrasah, pemilihan ini didasarkan atas proses analisis yang dilakukan sebelumya, karena untuk mendapatkan desain kurikulum yang baik, sesuai dengan kebutuhan dan tujuan madrasah harus diawali dengan sebuah perencanaan dan analisis. Apa yang dilakukan madrasah sesuai dengan apa yang dikemukakan oleh Fred Percival dan Henry Ellington dalam Hamalik yang mengemukakan bahwa desain kurikulum adalah merupakan pengembangan proses perencanaan, validasi, implementasi, dan evaluasi kurikulum.

Berdasarkan perspektif Subject Centered Desaign (SCD) sebaimana dijelaskan oleh Ornstein dan Hunkins dalam bukunya Curriculum: Foundation, Prinsciples, and Theory maka dapat dipahami bahwa subject centered design (SCD) sebagaimana dipilih dan diterapkan di madrasah Tsanawiyah Salafiyah Syafiiyah Tebuireng pada madrasah Tsanawiyah Negeri Tambakberas Jombang juga menerapkan bentuk-bentuk nya sebagai berikut: pertama, bentuk Subject Matter Design (SMD), kedua, bentuk diciplines design (DD), Ketiga, bentuk Broad Filed Design (BFD)

Walaupun subject centered design sebagai pilihan dalam mengkonstruksi kurikulum di madrasah ini, menurut hemat penulis,MTsN Tambakberas Jombang masih lebih dominan pada penggunaan bentuk subject matter design hal ini masih tercermin pada terpisahnya masing-masing mata pelajaran yang dituangkan dalam kurikulum, sedangkan dua bentuk yang lain masih belum nampak, meskipun sesungguhnya bentuk broad field design dapat dijadikan alternatif sebagai bentuk yang mampu menyiapkan kompetensi siswa pada spesialisasi badang-bidang tertentu. Artinya bahwa dalam mengkonstruk kurikulum madrasah tidak hanya berkonsentrasi pada satu bentuk saja tetapi juga perlu memasukkan bagian-bagian penting dari bentuk yang lain, dengan 
asumsi bahwa kurikulum pendidikan selalu mengalami perkembangan, termasuk kurikulum pendidikan di madrasah.

Berdasarkan uraian di atas dapat dipahami bahwa terdapat kesamaan pemilihan desain kurikulum yang diterapkan di madrasah Tsanawiyah salafiyah Syafi'iyah Tebuireng dengan madrasah Tsanawiyah Negeri Tambakberas Jombang yakni desain kurikulum model subject centered design bentuk subject matter design yaitu desain kurikulum yang menitiberatkan pada mata pelajaran.

\section{b. Pengembangan Kurikulum PAI}

Ibu Luluk Syarifatul Husniyah menjelasakan, bahwa MTsN Tambakberas ini dalam mengembangkan kurikulum madrasah telah menunjukkan langkahlangkah konkrit dengan memilih beberapa poin dan aspek penting, diantaranya: a) prinsip pengembangan kurikulum, b) komponen-komponen pengembangan kurikulum, dan 3) mekanisme pengembangan kurikulum.

Secara umum bahwa prinsip-prinsip pengembangan kurikulum tersebut meliputi: 1) prinsip relevansi, 2) prinsip fleksibilitas, 3) prinsip kontinuitas, 4) prinsip praktis, dan 5) prinsip efektivitas. Prinsip-prinsip tersebut seharusnya dipenuhi oleh madrasah pada saat melakukan pengembangan kurikulum. Namun demikian tidak semua madrasah memenuhi prinsip-prinsip tersebut.

Prinsip relevansi ini mempunyai kedekatan hubungan sesuatu dengan apa yang terjadi, Apabila dikaitkan dengan pendidikan, berarti perlunya kesesuaian antara program pendidikan dengan tuntutan kehidupan masyarakat. Terkait dengan prinsip relevansi ini MTsN Tambakberas mencoba memasukkan muatan-muatan materi yang tidak hanya terfokus pada kemampuan kognitif saja melainkan kemampuan aspek afektif dan psikomotorik siswa juga menjadi prioritas, misalnya materi-materi pembiasaan yang mencerminkan kesesuaian atau keserasian dengan lingkungan hidup di mana siswa berada. Karena berada di lingkungan pesantren, pembiasaan tersebut tercermin pada sikap tawadhu', cara bertutur kata, disiplin dalam mengikuti kegiatan keagamaan. Abdullah Idi mengatakan bahwa pendidikan itu dikatakan relevan apabila hasil yang diperoleh akan berguna bagi kehidupan seseorang. ${ }^{18}$

Selain Abdullah Idi, Sukmadinata juga mengatakan bahwa, terkait dengan prinsip relevansi terdapat dua relevansi yang yang harus dimiliki dalam program kurikulum yakni relevansi keluar dan relevansi kedalam. relevansi keluar diantaranya; (1) kesesuaian antara pendidikan dan lingkungan siswa, (2) kesesuaian antara pendidikan dengan kehidupan anak didik da saat sekarang dan yang akan datang, (3) kesesuaian antara pendidikan dengan dunia kerjanya bagi siswa, dan (4) kesesuaian antara pendidikan dengan perkembangan ilmu pengetahuan dan teknologi. Selain hal tersebut 
menurutnya bahwa kurikulum juga harus memiliki relevansi di dalam yaitu adanya kesesuaian antara tujuan, isi dan proses penyampaian dan penilaian. Relevansi internal ini menunjukkan suatu keterpaduan kurikulum ${ }^{19}$.

Selain prinsip relevansi tersebut ada juga prinsip kontinyuitas, dalam prinsip kontinyuitas ini perkembangan dan proses belajar peserta didik berlangsung secara berkesinambungan, tidak terputus-putus atau terhenti. Oleh karena itu, pengalaman-pengalaman belajar yang disediakan kurikulum juga hendaknya berkesinambungan antara satu tingkat kelas dengan kelas lainnya, antara satu jenjang pendidikan dengan jenjang lainnya.

Prinsip kontinyuitas ini digunakan oleh madrasah untuk menentukan kompetensi yang harus dimiliki siswa, dengan cara: 1) bahan pelajaran yang akan dibutuhkan di kelas yang lebih tinggi telah disampaikan atau diajarkan pada tingkat atau kelas sebelumnya atau bawahnya, 2) bahan pelajaran yang telah diajarkan pada kelas yang lebih rendah tidak harus diajarkan lagi pada kelas yang lebih tinggi, sehingga terhindar dari tumpang tindih dalam pengaturan bahan dalam proses belajar mengajar.

Pada prinsip ini sebagaimana yang telah dipaparkan oleh Sukmadinata ${ }^{20}$,bahwa prinsip kesinambungan dalam pengembangan kurikulum menunjukkan adanya saling terkait antara tingkat pendidikan, jenis program pendidikan, dan bidang studi, bahkan kesinambungan antara satu bidang studi dengan berbagai bidang studi lainnya untuk menghindari tumpang tindihnya materi yang dilaksanakan pada satuan pendidikan.

Selainprinsip-prinsip pengembangan tersebut madrasah juga menentukan komponen-komponen diantaranya materi kurikulum, metode atau strategi, tujuan dan juga evaluasi. Apa yang dilakukan madrasah nampaknya sesuai dengan apa yang diutarakan oleh Hilda Taba ${ }^{21}$, menurutnya bahwa komponen kurikulum itu terdiri dari; a) tujuan, b) materi, 3) metode atau strategi, dan 4) evaluasi.

Pada poin tujuan Robert S. Zaiz ${ }^{22}$ mengatakan bahwa, unsur tujuan merupakan kekuatan yang fundamental yang sangat peka, karena hasil kurikuler yang memberikan arah dan fokus seluruh program pendidikan. Dan pentingnya tujuan dalam proses pendidikan ini dikarenakan tidak ada satupun aspek-aspek pendidikan yang melupakan unsur tujuan. Lebih lanjut dia mempertegas, bahwa, pendidikan dalam setiap aspek-aspeknya selalu mempertanyakan tentang tujuan. Lebih lanjut, tujuan tersebut dapat dikelompokkan menjadi tiga bagian, yaitu tujuan umum (aims), tujuan

\footnotetext{
${ }^{19}$ Sukmadinata, Pengembangan Kurikulum, 124.

${ }^{20}$ Sukmadinata, Pengembangan Kurikulum, 151.

${ }^{21}$ Hilda Taba, Curriculum Development Theory and Practise (New York: Harcount Brace, Inc., 1972), 425.

${ }^{22}$ Robert S. Zais, “Curriculum Principles,” 297.
} 
instruksional umum (goals), dan tujuan instruksional khusus (objective), ketiga tujuan tersebut merupakan hirarki vertikal.

Apa yang dipahami oleh peneliti, bahwa madrasah dalam menentukan materi pelajaran yang akan dituangkan dalam kurikulum tersebut telah dilakukan dengan sangat selektif tetapi fleksibel. Selektif dimaksud bahwa materi kepesantrenan diambilkan dari kitab-kitab yang tidak hanya memberikan pengetahuan belaka tetapi sampai pada tingkat bagaimana amaliahnya/aplikasinya dalam kehidupan sehari-hari. Itu artinya kompetensi yang diinginkan dari materi tersebut tidak hanya aspek kognitif saja tetapi juga pada aspek afktif dan psikomotoriknya.

\section{c. Faktor-Faktor Pendukung dan Penghambat}

Berkaitan dengan faktor-faktor pendukung dan penghambat dalam mengkonstruk kurikulum di madrasah ini dijelsakan oleh Umi Mahmudah, bahwa segala bentuk kegiatan yang dilakukan oleh madrasah termasuk pengembangan kurikulum tersebut tidak lepas dari faktor-faktor yang mempengaruhinya baik itu faktor yang mendukung maupun faktor yang menghambatnya. Ketika faktor yang menghambat pengembangan kurikulumtersebut telah diketahui oleh madrasah sekalipun kecil sifat dan bentuknyamaka tidak boleh diangap ringan dan remeh, faktor-faktor tersebut segera dicarikan solusi terbaik dan logis untuk mengatasinya, jika tidak maka kegiatan yang dilakukan dapat menjadi gagal dan tidak mendapatkan keuntungan.

\section{Analisis Data}

\section{Analisis Data Lintas Kasus}

Analisis data lintas kasus dimaksudkan sebagai proses membandingkan datadata pada masing-masing kasus. Langkah-langkah yang dilakukan dalam analisis lintas kasus ini meliputi lima langkah sebagai berikut: (1) menggunakan pendekatan induktif konseptualistik yang dilakukan dengan membandingkan dan memadukan masing-masing kasus individu; (2) hasil perbandingan dan pemaduan dijadikan dasar untuk menyusun pernyataan konseptual atau proposisi lintas kasus; (3) mengevaluasi kesesuaian proposisi dengan fakta yang menjadi acuan; (4) mengkonstruksi ulang proposisi-proposisi sesuai fakta dari masing-masing kasus individu; (5) mengulangi proses ini sesuai dengan keperluan sampai batas kejenuhan.

\section{a. Analisis Lintas Kasus tentang Konstruksi Kurikulum PAI di Madrasah}

Konstruksi kurikulum PAI di madrasah yang dimaksudkan dalam penelitian ini adalah desain kurikulum yang digunakan pada empat madrasah yang diteliti dalam penelitian ini. Empat madrasah tersebut sama-sama menggunakan Subject Centered Design dengan perbandingan sebagai berikut: 
(1) MTs Salafiyah Syafi'iyah Tebuireng menerapkan Subject Centered Design: (1) membentuk tim pengembang kurikulum, (2) sinkronisasi keinginan tim Majelis Ilmi dan Madrasah, (3) pemetaan dan identifikasi tingkat kesulitan dan kemudahan materi, (4) pengampu materi sesuai dengan kualifikasi pendidik, dan (5) Membentuk MGMP: ICP, ALC, ILD.

(2) MTs Ar-Rahman Nglaban menerapkan Subject Centered Design: (1) membentuk tim penanggungjawab, (2) pemetaan materi sesuai denganSK/KD, (3) identifikasi kesulitan/kemudahan, dan (4) membentuk MGMP.

(3) MTsN Plandi Diwek menerapkan Subject Centered Design: (1) membentuktim pengembang kurikulum, (2) identifikasi mata pelajaran, (3) pemegangmapel sesuai dengan kualifikasi akademik, dan (4) membentuk MGMP.

(4) MTsN Tambakberas Jombang menerapkan Subject Centered Design:(1)membentuk tim pengembang kurikulum, (2) pengelompokan/ identifikasi mapel, (3) pemetaan guru mapel sesuai dengan sertifikat guru, (4) pembagian jam kerja guru PNS dan swasta, dan (5) distribusi tugas.

\section{b. Analisis Lintas Kasus tentang Pengembangan Kurikulum PAI di Madrasah}

Empat madrasah yang diteliti telah melakukan tahapan-tahapan dalam pengembangan kurikulum. Tahapan-tahapan tersebut sebagaimana yang dikemukakan oleh Oemar Hamalik, di antaranya; pertama, studi kelayakan dan kebutuhan; kedua, penyusunan konsep awal perencanaan kurikulum; ketiga, pengembangan rencana untuk pengembangan kurikulum; keempat, pelaksanaan uji coba kurikulum di lapangan; kelima, pelaksanaan kurikulum; keenam, pelaksanaan penilaian dan pemantauan kurikulum; dan ketujuh, pelaksanaan perbaikan dan penyesuaian. ${ }^{23}$

Dari ketujuh tahapan ini ada beberapa tahapan yang memiliki kelemahan, yaitu tahapan keempat tentang pelaksanaan uji coba kurikulumdi lapangan dan tahapan kelima tentang pelaksanaan kurikulum. Kelemahan pelaksanaan uji coba kurikulum biasanya tidak merata pada seluruh sekolah yang lokasinya sulit dijangkau, memerlukanbiaya besar dan keterbatasan tenaga serta terbatasnya fasilitas. Kelemahan pelaksanaan kurikulum adalah kadangkala tidak sesuai antara teori dan praktik di lapangan.

Selanjutnya tahap ketujuh, yakni pelaksanaan perbaikan dan penyesuaian. Pada tahap ini kebanyakan pengembang kurikulum setelah mengevaluasi kurikulum tidak merevisi kurikulum tersebut melainkan membuat kurikulum yang baru. Hal inilah yang membuat kurikulum tidak semakin baik melainkan menimbulkan permasalahan baru.

Beberapa persoalan muncul dalam pengembangan kurikulum PAI pada keempat madrasah ini, baik menyangkut komponen-komponen kurikulum

${ }^{23}$ Hamalik, Manajemen Pengembangan, 369. 
maupun yang berhubungan dengan tahap-tahap pengembangan kurikulum. Aspek komponen-komponen kurikulum mencakup (1) tujuan kurikulum, (2) isi dan struktur kurikulum, (3) strategi pelaksanaan kurikulum, dan (4) evaluasi kurikulum. Sedangkan tahap-tahap pengembangan kurikulum tersebut meliputi; (1) pengembangan program tingkat lembaga, (2) pengembangan program setiap mata pelajaran, dan (3) pengembangan program pengajaran di kelas.

Pengembangan kurikulum di madrasah baik pada keempat madrasah, jika dianalisis secara lintas kasus sebagaimana dijelaskan di atas terdapat perbedaan dan persamaan sebagai berikut:

(1) Dalam hal perencanaan pengembangan kurikulum keempat madrasah telah menempatkan bahwa musyawarah/diskusi antar pihak terkait terlebih dahulu dilakukan, ini sebagai perioritas utama yang didasari atas analisis kebutuhan dan tantangan masa depan. Selanjutnya menentukan komponen-komponen penting dalam kurikulum untuk menjadikan tim lebih fokus dalam pembahsannya. Berkaitan dengan penentuan materi tersebut pada MTs Salafiyah Syafi'iyah terlebih dahulu dikomunikasikan dengan majelis ilmi pesantren sebagai badan pertimbangan muatan materi yang terintegrasi dengan pesantren, begitu juga pada MTsN Tambakberas Jombang penentuan materi tersebut juga dikomunikasikan dengan yasayan dan Badan Pembina/Majelis Pengasuh Pondok Pesantren. Lain halnya dengan MTs Ar-Rahman dan MTsN Plandi Diwek, penentuan materi tersebut didiskusikan secara internal antara guru dan tim pengembang kurikulum madrasah.

(2) Dalam hal pelaksanaan, empat madrasah relatif sama, termasuk bukti adanya kelengkapan materi pelajaran dan perangkatnya sebelum pembelajaran dilaksanakan oleh guru, juga sama-sama melalui langkahlangkah sebagaimana pengembangan kurikulum secara umum, namun MTsN Plandi dan MTs Ar-Rahman belum melakukan langkah tahap uji coba kurikulum, berbeda dengan MTs Salafiyah Syafi'iah dan MTsN Tambakberas yang proses uji coba dilakukan sebelum kurikulum tersebut diterapkan.

(3) Evaluasi atau kontrol yang dilakukan oleh keempat madrasah relatif sama, yakni adanya model supervisi kelas yang dilakukan oleh kepala madrasah atau tim madrasah dan masing-masing juga menentukan tindak lanjut yang akan dilakukan. Pada MTs Salafiyah Syafi'iyah tindak lanjut tersebut lebih pada bagaimana menentukan model kurikulum yang akan digunakan, pada MTs Ar-Rahman masih pada evaluasi ulang terhadap kurikulum yang sedang digunakan artinya belum pada desain kurikulum baru, sedang pada MTsN Plandi tindak lanjut tersebut ada pada desain ulang serta renovasi kurikulum yang ada, begitu juga dengan MTsN Tambakberas yang juga mendesain ulang serta merekonstruksi kembali kurikulum yang ada di 
madrasah. Maka tampak sekali bahwa pada aspek evaluasi ini masingmasing madrasah memiliki model dan desain yang berbeda antara madrasah yang satu dengan madrasah lainnya.

\section{Temuan: Konstruksi Ideal Kurikulum Madrasah}

Penyajian dan analisis data penelitian di atas merupakan muara bagi penulis untuk menemukan temuan penelitian ini. Pada akhirnya penulis menemukan sebuah konstruksi kurikulum yang penulis beri nama "Madrasah'sCollaborative Curriculum" (Kurikulum Kolaboratif Madrasah) yang dapat disingkat "M-CC" atau "KK-M".

Sebagai temuan penelitian, Collaborative Curriculum Madrasah mempunyai ciriciri sebagai berikut:

a. Mengakomodasi masukan kurikuler dari stakeholderskedalam muatan kurikulum sesuai dengan kebutuhan untuk menerjemahkan visi, misi, dan tujuan pendidikan;

b. Mengakomodasi muatan kurikulum baru sesuai dengan tuntutan dinamika masyarakat, dengan tetap mempertahankan citra pokok kurikulum yang menjadi citra khas madrasah;

c. Melestarikan budaya keperilakuan yang menjadi citra utama madrasah sebagai penerjemahan "behavioral aspect" kurikulum.

d. Mengutamakan inisiatif untuk mengakomodasi potensi-potensi muatan kurikulum baru, masukan kurikuler stakeholders, dan citra utama madrasahkedalam desain kurikulum yang kreatif sesuai dengan visi, misi, dan tujuan pendidikan;

e. Ciri desain kurikulum yang kreatif adalah sebagai berikut:

1) Memilih dan menetapkan desain kurikulum yang dipandang tepat untuk memenuhi visi, misi, dan tujuan pendidikan,

2) Melakukan inovasi desain baru kurikulum sebagai alternatif baru sesuai dengan kebutuhan dan kemungkinan yang ada. 


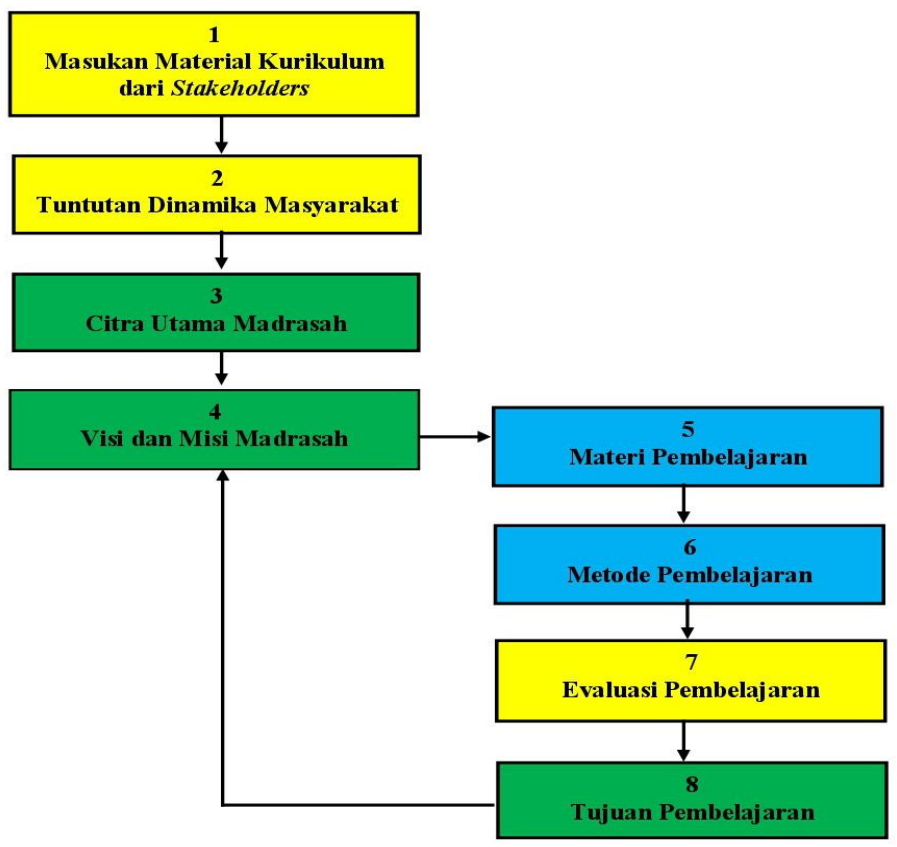

Gambar 1. Konstruksi Kurikulum Kolaboratif Madrasah

Kurikulum Kolaboratif(Collaborative Curricullum) dapat dipilih sebagai salah satu alternatif desain kurikulum PAI yang ideal di MTs baik negeri maupun swasta. Kurikulum Kolaboratif merupakan kurikulum yang memungkinkan siswa baik secara individual maupun klasikal aktif menggali dan menemukan konsep dan prinsip secara holistik bermakna dan otentik. Melalui pembelajaran kolaboratif siswa dapat memperoleh pengetahuan secara menyeluruh dengan cara mengaitkan satu pelajaran dengan pelajaran yang lain. Kurikulum kolaboratif merupakan kurikulum yang meniadakan batas-batas antara berbagai mata pelajaran dan menyajikan bahan-bahan dalam bentuk unit atau keseluruhan. Dengan demikian kurikulum ini mengintegrasikan komponen-komponen mata pelajaran sehingga batas-batas mata pelajaran tersebut sudah tidak nampak lagi dikarenakan telah dirumuskan dalam bentuk unit. Ciri-ciri bentuk kurikulum kolaboratif (collaborrative curriculum) diantaranya adalah: Pertama,mengakomodasi masukan kurikuler dari stakeholders kedalam muatan kurikulum sesuai dengan kebutuhan untuk menerjemahkan visi, misi, dan tujuan pendidikan. Kedua, mengakomodasi muatan kurikulum baru sesuai dengan tuntutan dinamika masyarakat, dengan tetap mempertahankancitra pokok kurikulum yang menjadi citra khas madrasah. Ketiga, melestarikan budaya keperilakuan yang menjadi citra utama madrasah sebagai penerjemahan "behavioral aspect" kurikulum. Keempat, mengutamakan inisiatif untuk mengakomodasi potensi-potensi muatan kurikulum baru, masukan kurikuler stakeholders, dan citra utama madrasah kedalam desain kurikulum yang kreatif sesuai dengan visi, misi, dan tujuan pendidikan. 
Madrasah dengan berbagai kelebihan dan kekurangannya perlu berupaya untuk membuktikan sebagai lembaga pendidikan yang memiliki nilai plus; nilai kekhasan yang wajib dibuktikan dan dipertahankan.Nilai-nilai tersebut dapat dibuktikan jika madrasah mampu mendesain kurikulum yang berbeda dengan sekolah lain. Madrasah di era milenial ini idealnyaharus lebih berani untuk melakukan inovasi-inovasi terkait dengan kurikulum pendidikan yang diterapkan, dengan tetap mempertimbangkan standar kurikulum yang ditetapkan oleh pemerintah. Sehingga perkembangan madrasah dapat menopang pekembangan pendidikan Islam di Indonesia.

\section{Kesimpulan}

Titik berat dari keempat kurikulum PAI di keempat madrasah yang diteliti adalah pemilihan Subject Centered Design, yang berfokus pada mata pelajaran. Kurikulum dikembangkan dengan prosedur sebagaimana pengembangan kurikulum pada umumnya, yaitu mengikuti mekanisme administrasi sekolah pada umumnya. Pada madrasah yang berada di lingkungan pesantren, kurikulum yang dikembangkan mengacu pada kompetensi yang dikembangkan di pesantren, yakni disamping kompetensi pada muatan kurikulum pemerintah juga kepesantrenan, terbukti adanya mata pelajaran pendamping terhadap mata pelajaran agama. Sebenarnya, kondisi di lapangan menunjukkan factor-faktor yang sangat dominan dalam mendukung pengembangan kurikulum lebih lanjut seperti keleluasaan madrasah untuk mendesain kurikulum dari pengambil kebijakan (yayasan), masih adanya pilihan alternatif yang bersifat fleksibel antara KTSP dan kurikulum 2013, dan tersedianya balai-balai pelatihan dibidang kurikulum. Namun demikian, di lapangan belum ditemukan adanya kesepahaman sumber daya manusia guru, penguasaan guru tentang teknologi informasi, dan sarana serta pendanaan meskipun prosentasenya kecil. Collaborative curriculum dapat menjadi pilihan dalam pengembangan kurikulum PAI pada konteks ini. Melalui pembelajaran kolaboratif siswa dapat memperoleh pengetahuan secara menyeluruh dengan cara mengaitkan satu pelajaran dengan pelajaran yang lain. Kurikulum ini mengintegrasikan komponen-komponen mata pelajaran sehingga batas-batas mata pelajaran tersebut sudah tidak nampak lagi dikarenakan telah dirumuskan dalam bentuk unit berdasarkan tema objek yang dikasi, bukan sudut pandang keilmuan dalam mengkajinya.

\section{E. Referensi}

Ali, Muhammad. Pengembangan Kurikulum di Sekolah. Bandung: Sinar Baru, 1992.

Hamalik, Oemar. Dasar-dasar Pengembangan Kurikulum. Bandung: Remaja Rosdakarya, 2008. 
--------. Manajemen Pengembangan Kurikulum. Bandung: Rosda, 2006.

Idi, Abdullah. Pengembangan Kurikulum Teori dan Praktik. Yogyakarta: Ar-Ruzz Media, 2010.

Janice, M. Marse. Critical Issues in Qualitative Research Methods. London: SAGE Publications, 1993.

Mudzaki, Abdul Mudjib dan Jusuf. Ilmu Pendidikan Islam. Jakarta: Prananda Media, 2006.

Muhaimin. Paradigma Pendidikan Islam, Upaya Mengefektifkan Pendidikan Agama Islam di Sekolah. Bandung: Remaja Rosdakarya, 2004.

--------. Rekonstruksi Pendidikan Islam, dari Paradigma Pengembangan, Manajemen Kelembagaan, Kurikulum hingga Strategi Pembelajaran. Jakarta: Rajawali Press, 2009.

Print, Murray. Curriculum Development and Design. Sydney: Allen and Unwin, 1993.

Qomar, Mujamil. Manajemen Pendidikan Islam. Jakarta: Erlangga, 2008.

Soemanto, Hendyat Soetopo dan W. Pembinaan dan Pengembangan Kurikulum. Jakarta: Bina Aksara, 1986.

Subandiyah. Pengembangan dan Inovasi Kurikulum. Jakarta: Raja Grafindo Persada, 1993.

Subhan, Muhammad, interview by Khoirul Umam. Wawancara, MTs Salafiyah Syafi'iyah Tebuireng (Februari 4, 2017).

Sukmadinata, Nana Syaodih. Pengembangan Kurikulum: Teori dan Praktik. Bandung: PT. Remaja Rosdakarya, 1997.

Sumantri, Mulyani. Pengembangan dan Pelaksanaan Kurikulum yang Menjamin Tercapainya Lulusan yang Kreatif, dalam Kurikulum untuk Abad 21. Jakarta: Grafindo Persada, 1994.

Taba, Hilda. Curriculum Development Theory and Practise. New York: Harcount Brace, Inc., 1972.

Tafsir, Ahmad. Ilmu Pendidikan Islam Perspektif Islam. Bandung: PT. Remaja Rosda Karya, 2006.

Zais, Robert S. Curriculum: Principles and Foundations. New York: Harper Row Publisher, 1976. 